\title{
Active Gold-Ceria and Gold-Ceria/Titania Catalysts for CO Oxidation: From Single-Crystal Model Catalysts to Powder Catalysts
}

\author{
José A. Rodriguez*a ${ }^{\mathrm{a}}$, Rui Si ${ }^{\mathrm{a}}$, Jaime Evans ${ }^{\mathrm{b}}$, Wenqian $\mathrm{Xu}^{\mathrm{a}}$, Jonathan C. Hanson ${ }^{\mathrm{a}}$, Jing \\ $\mathrm{Tao}^{\mathrm{c}}$, and Yimei $\mathrm{Zhu}^{\mathrm{c}}$ \\ ${ }^{a}$ Department of Chemistry, Brookhaven National Laboratory, Upton, NY, \\ ${ }^{b}$ Facultad de Ciencias, Universidad Central de Venezuela, Caracas 1020, Venezuela \\ ${ }^{b}$ Condensed Matter Physics and Materials Science Department, Brookhaven National
} Laboratory, Upton, $N Y$, *: Corresponding authors. E-mail addresses: rodrigez@bnl.gov (J.A. Rodriguez).

\begin{abstract}
$\mathrm{CO}$ oxidation was studied on model and powder catalysts of $\mathrm{Au}-\mathrm{CeO}_{2}$ and $\mathrm{Au}-\mathrm{CeO}_{\mathrm{x}} / \mathrm{TiO}_{2}$. Phenomena observed in $\mathrm{Au}-\mathrm{CeO}_{2}(111)$ and $\mathrm{Au}-\mathrm{CeO}_{2} / \mathrm{TiO}_{2}(110)$ provided useful concepts for designing and preparing highly active and stable $\mathrm{Au}-\mathrm{CeO}_{\mathrm{x}} / \mathrm{TiO}_{2}$ powder catalysts for $\mathrm{CO}$ oxidation. Small particles of $\mathrm{Au}$ dispersed on $\mathrm{CeO}_{2}(111)$ displayed high catalytic activity, making $\mathrm{Au}-\mathrm{CeO}_{2}(111)$ a better $\mathrm{CO}$ oxidation catalyst than $\mathrm{Au}-\mathrm{TiO}_{2}(110)$ or $\mathrm{Au}-$ $\mathrm{MgO}(100)$. An excellent support for gold was found after depositing nanoparticles of ceria on $\mathrm{TiO}_{2}(110)$. The $\mathrm{CeO}_{\mathrm{x}}$ nanoparticles act as nucleation centers for gold, improving dispersion of the supported metal and helping in the creation of reaction sites efficient for the adsorption of $\mathrm{CO}$ and the dissociation of the $\mathrm{O}_{2}$ molecule. High-surface area catalysts were prepared by depositing gold on ceria nanorods and $\mathrm{CeO}_{\mathrm{x}} / \mathrm{TiO}_{2}$ powders. The samples were tested for the low-temperature $\left(10-70{ }^{\circ} \mathrm{C}\right)$ oxygen-rich $\left(1 \% \mathrm{CO} / 4 \% \mathrm{O}_{2} / \mathrm{He}\right)$ $\mathrm{CO}$ oxidation reaction after pre-oxidation $\left(20 \% \mathrm{O}_{2} / \mathrm{He}, 300{ }^{\circ} \mathrm{C}\right)$ and pre-reduction $\left(5 \% \mathrm{H}_{2} / \mathrm{He}, 300{ }^{\circ} \mathrm{C}\right)$ treatments. Synchrotron-based operando X-ray diffraction (XRD) and X-ray absorption (XAS) spectroscopy were used to study the $\mathrm{Au}-\mathrm{CeO}_{2}$ and $\mathrm{Au}$ $\mathrm{CeO}_{\mathrm{x}} / \mathrm{TiO}_{2}$ catalysts under reaction conditions. Our operando findings indicate that the most active phase of these catalysts for low-temperature $\mathrm{CO}$ oxidation consist of small particles of metallic $\mathrm{Au}$ dispersed on $\mathrm{CeO}_{2}$ or $\mathrm{CeO}_{\mathrm{x}} / \mathrm{TiO}_{2}$.
\end{abstract}

Keywords: Gold; Ceria; Titania; CO oxidation; X-ray diffraction; X-ray absorption; Active site

\section{Introduction}


Although bulk gold materials have normally shown poor activity as catalysts, Au nanoparticles strongly interacting with the oxide supports were first described by Haruta et al. to be extremely active CO oxidation catalyst in 1989 [1]. Numerous studies since then have been reported to confirm the activity of well dispersed gold species for the $\mathrm{CO}$ oxidation reaction [2-21], and to explore the role of the oxide support using various reducible oxides including titania $\left(\mathrm{TiO}_{2}\right)$ [2-5], iron oxide $\left(\mathrm{FeO}_{x}\right)$ [6-9] and ceria $\left(\mathrm{CeO}_{2}\right)$ [7, 9-21], and non-reducible oxides such as silica $\left(\mathrm{SiO}_{2}\right)[5,22]$ and alumina $\left(\mathrm{Al}_{2} \mathrm{O}_{3}\right)$ [5]. While a full mechanism of this catalytic process still needs to be established, the nature of the support is commonly considered to be one of the key factors for dispersion and stabilization of ultra-fine gold structures and the activation of $\mathrm{CO}$ oxidation catalysts.

Ceria, as one of the most important rare earth oxides, has been extensively applied in catalysis and electrocatalysis due to its unique physical and chemical properties. The ability of cerium to switch between $\mathrm{Ce}^{4+}$ and $\mathrm{Ce}^{3+}$ oxidation states, releasing or storing oxygen, makes ceria an active oxide component of various oxidation catalysts used in diverse redox catalytic reactions. $\mathrm{CeO}_{2}$ retains its fluorite-type crystal structure during the oxygen storage and release processes. To further improve the performance of $\mathrm{Au}-\mathrm{CeO}_{2}$ catalysts for the $\mathrm{CO}$ oxidation reaction, different preparation methods, including deposition-precipitation (DP) [7, 12-17], coprecipitation [9, 17], and urea-gelation coprecipitation [7], have been used to control and optimize the interaction of the Au-OCe structure, as well as the size and shape of ceria. The oxide support, especially if it is reducible, is included in the mechanism, as a source of active oxygen for the redox reactions. Thus, the basic questions regarding the structure-activity relationship and the interaction of gold and ceria in the low-temperature $\mathrm{CO}$ oxidation reaction have been addressed, but often with divergent conclusions. In our opinion, a careful investigation of the reported strong metal-support interaction through structural studies may provide further mechanistic insights as well as rationalize the design of practical catalysts. 
Considering the oxidation state of gold in the active catalysts, different gold species have been proposed for various redox reactions. For instance, gold cations or positively charged nanoclusters $(<1 \mathrm{~nm})$, comprising a few gold atoms are the active sites for the water-gas shift (WGS) reaction [23-25], while for CO oxidation reaction, there are still arguments whether $\sim 3 \mathrm{~nm}$ Au particles on $\mathrm{TiO}_{2}[2]$ or $\mathrm{Ce}(\mathrm{La}) \mathrm{O}_{x}$ [7] are most active or bilayer gold clusters $(0.5 \mathrm{~nm}$ in size $)$ on $\mathrm{Fe}_{2} \mathrm{O}_{3}$ [8] effectively catalyze the $\mathrm{CO}$ oxidation reaction. Furthermore, due to the difficulties in controlling the catalyst structure, there is no direct evidence showing the location of the active sites yet. The Au surface, the support surface (especially $\mathrm{Ce}^{3+}$ or oxygen vacancies $[10,21,26]$ ), or the gold/support interface all have been suggested as important for the catalytic activity. Therefore, operando characterizations [27], such as X-ray absorption spectroscopy (XAS), X-ray diffraction (XRD), and diffuse reflectance Infra-red Fourier transform (DRIFTS), are required to monitor the catalytic process; probe the active phase for the gold-ceria catalyst and unravel the reaction mechanism for the $\mathrm{CO}$ oxidation reaction.

In this paper, we use model single-crystal and powder catalyst to study the effect of the Au-ceria interactions on the activity of gold towards $\mathrm{CO}$ oxidation. To maximize $\mathrm{Au}-$ ceria interactions, we co-deposit nanoparticles of $\mathrm{Au}$ and ceria on titania or use ceria nanorods as a support. Previously, catalysts involving gold and ceria nanorods have been proved to be highly active for the water-gas shift (WGS) process [28], methanol steam reforming [29], and CO oxidation [16, 30]. In our study with the powder catalysts, we will focus on operando XAS \& XRD characterizations, monitoring the structural changes of gold species and the oxide support under realistic reaction conditions, and determining the active phase for the low-temperature oxygen-rich $\mathrm{CO}$ oxidation. Our study shows that $\mathrm{Au} / \mathrm{CeO}_{\mathrm{x}} / \mathrm{TiO}_{2}$ powders are highly active and stable catalysts for this process. 


\section{Experimental Section}

2.1 Studies with $\mathrm{Au} / \mathrm{CeO}_{2}(111)$ and $\mathrm{Au} / \mathrm{CeO}_{x} / \mathrm{TiO}_{2}(110)$ : The studies with model catalysts were performed in a system which combines an ultrahigh-vacuum (UHV) chamber (base pressure $\sim 5 \times 10^{-10}$ Torr) and a batch reactor $[10,20]$. The sample could be transferred between the reactor and UHV chamber without exposure to air. The UHV chamber (base pressure $\sim 5 \times 10^{-10}$ Torr) was equipped with instrumentation for X-ray and ultraviolet photoelectron spectroscopies (XPS and UPS), low-energy electron diffraction (LEED), ion scattering spectroscopy (ISS), and temperature-programmed desorption (TPD) [20]. The $\mathrm{Au} / \mathrm{CeO}_{2}(111)$ and $\mathrm{Au} / \mathrm{CeO}_{x} / \mathrm{TiO}_{2}(110)$ catalysts were prepared following a methodology described in previous studies [10,20]. Au was evaporated on $\mathrm{CeO}_{2}(111)$ and $\mathrm{CeO}_{x} / \mathrm{TiO}_{2}(110)$ at $25^{\circ} \mathrm{C}$. In the kinetic measurements the sample was transferred to the batch reactor at $\sim 25{ }^{\circ} \mathrm{C}$, then the reactant gases were introduced (4 Torr of $\mathrm{CO}$ and 2 Torr of $\mathrm{O}_{2}$ ) and the sample was hold at a reaction temperature of $27{ }^{\circ} \mathrm{C}$. The amount of molecules produced was normalized by the geometric area exposed of the $\mathrm{CeO}_{2}(111)$ and $\mathrm{TiO}_{2}(110)$ samples $[10,20]$.

\subsection{Studies with $\mathrm{Au}-\mathrm{CeO}_{2}$ nanorods and $\mathrm{Au}-\mathrm{CeO}_{x} / \mathrm{TiO}_{2}$}

A. Synthesis of $\mathrm{Au}-\mathrm{CeO}_{2}$ nanorods: For the hydrothermal preparation of ceria nanorods [28], $\mathrm{Ce}\left(\mathrm{NO}_{3}\right)_{3} \cdot 6 \mathrm{H}_{2} \mathrm{O}(99.5 \%$, Alfa; $4.5 \mathrm{mmol})$ was dissolved in $90 \mathrm{~mL}$ of an aqueous $\mathrm{NaOH}(98 \%$, Alfa) solution of $6 \mathrm{~mol} / \mathrm{L}$. This stock solution was stirred at room temperature for $10 \mathrm{~min}$ in a Teflon bottle and then sealed tightly in a stainless-steel autoclave. Hydrothermal treatment was carried out at $100{ }^{\circ} \mathrm{C}$ for $24 \mathrm{~h}$. After cooling, the white precipitates obtained were collected, washed with deionized (DI) water, and dried in vacuo at $70-80{ }^{\circ} \mathrm{C}$ overnight. The dried yellow powders were calcined in air at $400{ }^{\circ} \mathrm{C}$ for $4 \mathrm{~h}$. For the gold deposition-precipitation (DP), $3 \mathrm{~g}$ of $\mathrm{CeO}_{2}$ powder were slurried in DI water $(150 \mathrm{~mL})$ whilst stirring and an aqueous $\left(\mathrm{NH}_{4}\right)_{2} \mathrm{CO}_{3}$ solution $(75 \mathrm{~mL} ; 1 \mathrm{~m})$ was 
then added. $\mathrm{HAuCl}_{4} \cdot 3 \mathrm{H}_{2} \mathrm{O}(99.99 \%$, Alfa; $0.174 \mathrm{mmol})$ was dissolved in DI water (75 $\mathrm{mL}$ ) and added to the above solution dropwise. The $\mathrm{pH}$ value was kept at 8-9 during the whole process. The resulting precipitate was aged at room temperature for $1 \mathrm{~h}$, then filtered and washed three times with DI water at $60-70{ }^{\circ} \mathrm{C}$. The product was dried in vacuo at $70-80{ }^{\circ} \mathrm{C}$ overnight and then calcined in air at $400{ }^{\circ} \mathrm{C}$ for 4 hours (fresh catalyst).

B. Synthesis of the $\mathrm{CeO}_{2}$-modified $\mathrm{TiO}_{2}$ support and the $\mathrm{Au} / \mathrm{CeO} \mathrm{O}_{x} / \mathrm{TiO}_{2}$ catalyst: The $\mathrm{TiO}_{2}$ support (titanium (IV) oxide, Alfa Aesar) was pretreated in still air at $500{ }^{\circ} \mathrm{C}$ for $4 \mathrm{~h}$. The $\mathrm{CeO}_{2}$-modified $\mathrm{TiO}_{2}$ support, $\mathrm{Ti}(x \mathrm{Ce}) \mathrm{O}_{2}\left(x\right.$ is the weight percentage of $\mathrm{CeO}_{2} ; x=0,6$ or 15 in this work), was prepared by wet impregnation of pretreated $\mathrm{TiO}_{2}$ powders with aqueous solution of cerium nitrate (Alfa Aesar, 99.5\%) [27]. After cerium impregnation the solid was calcined under air at $500{ }^{\circ} \mathrm{C}$ for $4 \mathrm{~h}$.

For the gold deposition-precipitation (DP) [27], 1-1.5 grams of $\mathrm{CeO}_{\mathrm{x}} / \mathrm{TiO}_{2}$ powder were slurried in DI water $(100 \mathrm{~mL})$ whilst stirring and an aqueous $\left(\mathrm{NH}_{4}\right)_{2} \mathrm{CO}_{3}$ solution $(25 \mathrm{~mL} ; 1 \mathrm{~mol} / \mathrm{L})$ was then added. $\mathrm{HAuCl}_{4} \cdot 3 \mathrm{H}_{2} \mathrm{O}(99.99 \%$, Alfa) was dissolved in DI water $(25 \mathrm{~mL})$ and added to the above solution dropwise. The gold loading amount was designed to be 1 at.\% with respect to $\mathrm{CeO}_{\mathrm{x}} / \mathrm{TiO}_{2}$. The $\mathrm{pH}$ value was kept at $8-9$ during the whole process. The resulting precipitates were aged at room temperature for $1 \mathrm{~h}$, then filtered and washed three times with DI water. The product was dried in vacuo at room temperature for 2-3 days thoroughly and tested without any pretreatment (fresh catalyst). We found that appropriate drying in vacuum and storage in cold and dark conditions were very important to maintain the ultra-fine gold species on ceria-modified $\mathrm{TiO}_{2}$. The powder samples used in this study will be denoted as $\mathrm{Au}-\mathrm{Ti}(15 \mathrm{Ce}) \mathrm{O}_{2}\{1$ at.\% Au on $\left.15 \mathrm{wt} \%-\mathrm{CeOx} / \mathrm{TiO}_{2}\right\}$. 
C. Transmission electron microscopy (TEM): TEM and high-resolution TEM (HRTEM) images were obtained using a JEOL2100F microscopy equipped with a $2 \mathrm{k} \times 2 \mathrm{k}$ CCD camera at the Center of Functional Nanomaterials (CFN) at Brookhaven National Laboratory.

D. X-ray diffraction: The time-resolved X-ray diffraction experiments were carried out on beamline X7B $(\lambda=0.3196 \AA)$ of the National Synchrotron Light Source (NSLS) at Brookhaven National Laboratory. The powder sample $(\sim 20 \mathrm{mg})$ was loaded into a Kapton tube (O.D. $=0.125$ inch) which was attached to a flow system. Two small resistance heating wires were installed right above and below the in-situ cell, and the temperature was monitored with a 0.5 -mm chromel-alumel thermocouple that was placed inside the tube near the sample. In-situ diffraction patterns were collected during CO oxidation reaction $\left(1 \% \mathrm{CO} / 4 \% \mathrm{O}_{2} / \mathrm{He}, 20 \mathrm{~mL} / \mathrm{min}, \sim 100,000 \mathrm{~h}^{-1}\right)$ under a "steady-state" mode between -65 and $70{ }^{\circ} \mathrm{C}\left(15{ }^{\circ} \mathrm{C} /\right.$ step, 30 min each $)$. The fresh $\mathrm{Au}-\mathrm{CeO}_{2}$ catalysts were pre-oxidized $\left(20 \% \mathrm{O}_{2} / \mathrm{He}, 300{ }^{\circ} \mathrm{C}, 1 \mathrm{~h}\right)$ or pre-reduced $\left(5 \% \mathrm{H}_{2} / \mathrm{He}, 200{ }^{\circ} \mathrm{C}, 1 \mathrm{~h}\right)$ before the reaction. For the temperatures below room-temperature, the powder sample was cooled by a nitrogen liquid/flow gun. Two-dimensional powder patterns were collected with an image-plate detector (Perkin-Elmer), and the powder rings were integrated using the FIT2D code [31]. The lattice constants of ceria were calculated through Rietveld refinement [32]. The catalyst sample was mounted on a micro-reactor suited for operando studies as a function of temperature $\left(-100{ }^{\circ} \mathrm{C}\right.$ to $\left.800{ }^{\circ} \mathrm{C}\right)$ and pressures (1-5 atm) [27]. For the activity measurement, $\mathrm{CO}(m / e=28)$ and $\mathrm{CO}_{2}(m / e=44)$ concentrations in the outlet of the micro-reactor were continuously determined by a residual gas analyzer (RGA). 
E. X-ray absorption spectroscopy: Au L-III absorption edge $\left(E_{0}=11919 \mathrm{eV}\right)$ XAFS spectra were collected in-situ at beamline X19A of the NSLS at BNL during the CO oxidation reaction under similar conditions as the XRD experiments with the exception of the testing temperature was always kept at $25{ }^{\circ} \mathrm{C}$. The X-ray absorption spectra were taken repeatedly in the "fluorescence-yield mode" using a Vortex detector. The energy was calibrated for each scan with the first inflection point of the Au L-III-edge in Au metal foil. The EXAFS data have been analyzed using the Athena and Artimis programs [33].

\section{Results}

\section{1 $\mathrm{CO}$ oxidation on $\mathrm{Au} / \mathrm{CeO}_{2}(111)$ and $\mathrm{Au} / \mathrm{CeO}_{x} / \mathrm{Ti}(110)$ catalysts}

Studies of scanning-tunneling microscopy (STM) indicate that Au grows on $\mathrm{CeO}_{2}$ (111) forming three-dimensional (3D) particles that bind to the steps and defects in the terraces of the surface [11]. The bonding of the Au particles to the oxide substrate is relatively weak and the interaction of the particles with a gas mixture of $\mathrm{CO}$ and $\mathrm{O}_{2}$ induced segregation [11]. Figure 1 displays the $\mathrm{CO}$ oxidation activity of $\mathrm{Au} / \mathrm{CeO}_{2}(111)$ as a function of Au coverage. A maximum in the production of $\mathrm{CO}_{2}$ is seen at $\mathrm{Au}$ coverages of 0.3-0.4 ML. Previous studies have shown that there is a marked size effect on the catalytic activity of gold $[1,2,6]$. Comparing our $\mathrm{CO}$ oxidation results with the particle size seen in STM for $\mathrm{Au} / \mathrm{CeO}_{2}(111)$ [11], one can conclude that Au particles in the range of 1-3 nm exhibit the highest activity, with a drop in catalytic activity for Au particles with sizes above $4 \mathrm{~nm}$. The maximum catalytic activities found for the $\mathrm{Au} / \mathrm{CeO}_{2}(111)$ systems are close to those measured in our laboratory for $\mathrm{Au} / \mathrm{TiO}_{2}(110)$ surfaces [10] and much better than those found for $\mathrm{Au} / \mathrm{MgO}(100)$, see Figure 2. Thus, the 
data obtained with the model catalysts indicate that the nature of the oxide support affects catalytic activity, in agreement with results obtained with powder catalysts $[1,2,28]$.

Studies of STM indicate that, as in the case of $\mathrm{Au} / \mathrm{CeO}_{2}(111)$ [11], gold grows on $\mathrm{TiO}_{2}(110)$ forming 3D particles anchored on steps and defect sites of the surface [2]. A drastic increase in the population of gold on the surface terraces can be obtained by depositing ceria nanoparticles on the $\mathrm{TiO}_{2}(110)$ substrate [10,27]. The ceria nanoparticles act as nucleation centers for small clusters and particles of gold [10,27]. We investigated the activity for $\mathrm{CO}$ oxidation of $\mathrm{Au} / \mathrm{CeO}_{\mathrm{x}} / \mathrm{TiO}_{2}(110)$ surfaces, see Figure 1 . In these studies the titania surface was pre-covered by $\sim 8 \%$ or $27 \%$ of ceria before depositing the Au. Figure 1 shows the production of $\mathrm{CO}_{2}$ over $\mathrm{Au} / \mathrm{CeO}_{\mathrm{x}} / \mathrm{TiO}_{2}(110)$ catalysts as a function of gold coverage. Maxima of activity are found at gold coverages of 0.4-0.5 ML. The $\mathrm{Au} / \mathrm{CeO}_{\mathrm{x}} / \mathrm{TiO}_{2}(110)$ systems are 4-5 times more active than $\mathrm{Au} / \mathrm{CeO}_{2}(111)$ or $\mathrm{Au} / \mathrm{TiO}_{2}(110)$. This, in part, can be a consequence of a better dispersion of $\mathrm{Au}$ on the terraces of the oxide support [10,27]. In addition, the ceria nanoparticles are more chemically active than bulk ceria $[10,27]$ and can help with the dissociation of $\mathrm{O}_{2}[10,26]$. The drop in the catalytic activity seen when going from a titania surface pre-covered by $8 \%$ of ceria to a surface pre-covered by $27 \%$ of ceria probably reflects a decrease in the dispersion of gold [10] and a reduction in the reactivity of the supported ceria $[10,26]$. The best catalysts in Figure 1 contain small amounts of Au and ceria.

Post-reaction characterization with XPS indicated that the active phase of the $\mathrm{Au} / \mathrm{CeO}_{2}(111)$ and $\mathrm{Au} / \mathrm{CeO}_{\mathrm{x}} / \mathrm{TiO}_{2}(110)$ catalysts contained metallic $\mathrm{Au}$, as seen in previous studies with model single-crystal catalysts [2], and some carbonate species probably associated with the oxide support.

\section{2 $\mathrm{CO}$ oxidation on $\mathrm{Au} / \mathrm{CeO}_{2}$ nanorods}

From the results in Figure 1, it is clear that one must maximize gold-ceria interactions to obtain a good performance during the oxidation of CO. On the basis of this, we decided 
to investigate the behavior of catalysts generated by depositing gold on ceria nanorods [28]. Figure 3a is the TEM image of a fresh 1 at. $\% \mathrm{Au}-\mathrm{CeO}_{2}$ catalyst after air-calcination at $400{ }^{\circ} \mathrm{C}$. Rod-like nanocrystals with the widths of ca. $10 \mathrm{~nm}$ and lengths of around 50 $\mathrm{nm}$ were observed. It agrees with previous reports on the nanoshapes of ceria $[34,35]$ and gold-ceria nanorods [28], which are enclosed by $\{110\}$ and $\{100\}$ facets of the oxide. In the gold-ceria system displayed in Figure 3a, the gold species are very well dispersed over the ceria substrate and no big gold particles are observed. No obvious morphology changes were detected by TEM or HRTEM when the Au/ceria catalysts were pre-treated in $\mathrm{O}_{2}$ (Fig 3b) or pre-reduced in $\mathrm{H}_{2}$ (Fig. 3c and 3d). Furthermore, we investigated hundreds of nanorods in HRTEM with the aids of fast Fourier transform (FFT) and found only evidence for a high dispersion of small gold particles.

The steady-state "light-off" profiles of the $\mathrm{Au}-\mathrm{CeO}_{2}$ nanorods with different pretreatments were measured at temperatures between 10 and $70{ }^{\circ} \mathrm{C}$. XANES spectra indicated that the fresh or as-prepared catalysts contained $\mathrm{AuO}_{\mathrm{x}}$ dispersed on ceria (see below). Pre-reduction of the $\mathrm{Au}-\mathrm{CeO}_{2}$ nanorods with $\mathrm{H}_{2}$ led to a $\mathrm{AuO}_{\mathrm{x}}$ à $\mathrm{Au}$ transformation and the generation of very active catalysts. Figure 4 shows the CO conversion for a pre-reduced $\mathrm{Au}-\mathrm{CeO}_{2}$ catalyst as a function of temperature. At $50{ }^{\circ} \mathrm{C}$ and temperatures above, the conversion of CO is essentially 100\%. This high conversion was maintained after several cycles of cooling and heating.

Figure 5 displays operando XRD patterns collected for pre-reduced $\mathrm{Au}-\mathrm{CeO}_{2}$ at different temperatures $\left(\mathrm{T}=10-70{ }^{\circ} \mathrm{C}\right)$ under $\mathrm{CO}$ oxidation conditions. Fluorite cubic $\mathrm{CeO}_{2}\left(F_{\mathrm{m}-3 \mathrm{~m}}\right.$, JCPDS card \#: 34-394) is the major phase in the Au-CeO $\mathrm{C}_{2}$ catalyst seen throughout the whole operando studies. In addition, a very weak XRD peak assigned to the $\mathrm{Au}(111)$ diffraction is seen (close to $8^{\circ}$ in 2 ). We used the General Structure Analysis System (GSAS) software to run a sequential Rietveld refinement [32] on the XRD profiles of the $\mathrm{Au}-\mathrm{CeO}_{2}$ ceria nanorod catalyst. This analysis indicated that the averaged 
cell dimensions for the $\mathrm{CeO}_{2}$ support during the operando XRD measurements remained constant around a value of $5.40 \AA$.

Operando XAFS measurements at the $\mathrm{Au}$ L-III edge for the pretreated $\mathrm{Au}-\mathrm{CeO}_{2}$ catalysts were carried out under the same testing conditions as the XRD studies, except that the reaction temperature was maintained at $25^{\circ} \mathrm{C}$. The line shapes of the two spectra (fresh and used) in Figure 6 for a pre-oxidized sample show a clear feature at $2.5 \mathrm{eV}$ above the edge, which is characteristic of ionic gold in $\mathrm{Au}_{2} \mathrm{O}_{3}[36,37,38]$. Compared with the fresh catalyst, the used pre-oxidized $\mathrm{Au}-\mathrm{CeO}_{2}$ nanorods display a lower intensity of the white-line, indicating the partial reduction of $\mathrm{Au}^{3+}$ species during the $\mathrm{CO}$ oxidation reaction at room-temperature. On the other hand, both fresh and used profiles for the prereduced sample have the typical characteristics of metallic gold $\left(\mathrm{Au}^{0}\right)[36,37,38]$ in the operando XANES experiments.

Using the operando XANES data, linear combination calculations [39] were done to determine the variation of the cationic and metallic Au species in the pre-oxidized and pre-reduced $\mathrm{Au}-\mathrm{CeO}_{2}$ catalysts under reaction conditions. The fresh pre-oxidized and prereduced $\mathrm{Au}-\mathrm{CeO}_{2}$ catalysts were used as the reference components and labelled as "OX" (oxidized) and "RE" (reduced), respectively. The results of the linear combination calculations are displayed in Figure 7. It can be clearly seen that gold was kept in a metallic form ("RE") during the whole $\mathrm{CO}$ oxidation reaction for the pre-reduced sample (red points); while the oxidation states of Au changed from pure "OX" to a mixture of roughly $70 \%$ "OX" $+30 \%$ "RE" after $10 \mathrm{~h}$ reaction at room-temperature for the preoxidized sample (blue points).

Considering the data in Figure 7 together with the catalytic activity measured for preoxidized and pre-reduced $\mathrm{Au}-\mathrm{CeO}_{2}$ catalysts, we can draw the following conclusions on the relationship between the gold oxidation state and the $\mathrm{CO}$ oxidation reactivity. (1) 
Both ionic and metallic gold are catalytically active, since the pre-oxidized (Au-O) and pre-reduced $(\mathrm{Au}-\mathrm{Au})$ catalysts showed good $\mathrm{CO}$ oxidation activities. (2) Metallic gold is more active than ionic $\mathrm{Au}$. The activation of the pre-oxidized $\mathrm{Au}-\mathrm{CeO}_{2}$ nanorods was accompanied by the gradual reduction of gold species in the catalyst. Figure 8 illustrates two possible routes to enhance the activity of gold-ceria nanostructures under different reaction conditions. A pre-oxidized sample with a main phase of Au cations or positivechanged clusters (structure 1) is less active for the low-temperature $\mathrm{CO}$ oxidation reaction. The pre-reduced catalyst with dominant metallic gold species (structure 2) or the preoxidized and used $\mathrm{Au}-\mathrm{CeO}_{2}$ nanorods with an increased $\mathrm{Au}^{0}$ fraction (structure 3) are more active. In any case, the ceria nanorod support is predominantly kept in an oxidized $\mathrm{Ce}^{4+}$ form.

\section{$3.3 \mathrm{CO}$ oxidation on $\mathrm{Au} / \mathrm{CeO}_{x} / \mathrm{TiO}_{2}$ powders}

The results of XANES indicated that the as-prepared $\mathrm{Au} / \mathrm{CeO}_{\mathrm{x}} / \mathrm{TiO}_{2}$ samples contained $\mathrm{AuO}_{\mathrm{x}}$ dispersed on top of the ceria-titania support. Following the study with the Au-ceria nanorods, the $\mathrm{Au} / \mathrm{CeO}_{\mathrm{x}} / \mathrm{TiO}_{2}$ samples were pre-reduced with $\mathrm{H}_{2}$ to induce a $\mathrm{AuO}_{\mathrm{x}}$ à $\mathrm{Au}$ transformation and generate a highly active catalyst for $\mathrm{CO}$ oxidation. Figure 9 displays TEM images for a pre-reduced $\mathrm{Au} / \mathrm{CeO}_{\mathrm{x}} / \mathrm{TiO}_{2}$ system. Large irregular nonuniform $(10-100 \mathrm{~nm}) \mathrm{TiO}_{2}$ (anatase + rutile) particles are the main textural phase in the catalytic material. The HRTEM image in Figure 9B clearly confirms the presence of ultrafine gold nanoparticles on all the ceria-modified titania support. The average Au size was calculated to be around $1 \mathrm{~nm}$ in the catalyst. With the aid of EDX, we were able to identify the morphology of $\mathrm{CeO}_{x}$ supported on titania. The related ceria particle size was 5-7 nm, much smaller than that of the titania support. Previous studies have shown that ceria grows on titania forming very small clusters, plates and 3D nanoparticles [40]. At the ceria-titania interface, there is an intermixing of the two oxides that favors the 
formation of $\mathrm{Ce}^{3+}$ cations $[40,41]$. We found that a large fraction of the $\mathrm{Au}$ and $\mathrm{CeO}_{\mathrm{x}}$ nanoparticles in $\mathrm{Au} / \mathrm{CeO}_{x} / \mathrm{TiO}_{2}$ were in contact with each other.

The steady-state "light-off" profile for a pre-reduced $\mathrm{Au} / \mathrm{CeO}_{\mathrm{x}} / \mathrm{TiO}_{2}$ catalyst is shown in Figure 4. The $\mathrm{Au} / \mathrm{CeO}_{\mathrm{x}} / \mathrm{TiO}_{2}$ is highly active for $\mathrm{CO}$ oxidation reaching a conversion close to $100 \%$ at $30{ }^{\circ} \mathrm{C}$. In general, we found that the $\mathrm{Au} / \mathrm{CeO}_{\mathrm{x}} / \mathrm{TiO}_{2}$ powders were more active for $\mathrm{CO}$ oxidation than $\mathrm{Au} /$ ceria nanorods, in good agreement with trend seen in Figure 1 for the model $\mathrm{Au} / \mathrm{CeO}_{2}(111)$ and $\mathrm{Au} / \mathrm{CeO}_{\mathrm{x}} / \mathrm{TiO}_{2}(110)$ catalysts. In stability tests, see Figure 10, we found no sign for deactivation of a $\mathrm{Au} / \mathrm{CeO}_{\mathrm{x}} / \mathrm{TiO}_{2}$ catalyst after 20 hours of operation. This probably reflects the strong interaction that exists between the gold and ceria nanoparticles which prevents sintering and deactivation of the catalyst [27].

Operando studies with XANES showed that the gold in pre-reduced $\mathrm{Au} / \mathrm{CeO}_{\mathrm{x}} / \mathrm{TiO}_{2}$ remained in a metallic state during the oxidation of $\mathrm{CO}$. On the other hand, the cerium was fully oxidized in a +4 state. The complete oxidation of cerium is expected due to the large ratio of $4 / 1$ used for $\mathrm{O}_{2} / \mathrm{CO}$ in our experiments. In a set of experiments pulsing $\mathrm{O}_{2}$ and $\mathrm{CO}$ in a sequential manner over a $\mathrm{Au} / \mathrm{CeO}_{\mathrm{x}} / \mathrm{TiO}_{2}$ catalyst, we found a fast $\mathrm{Ce}^{4+} \mathrm{Ce}^{3+}$ switching, which is consistent with the idea that ceria nanoparticles dissociate $\mathrm{O}_{2}$ fast and do not hold $\mathrm{O}$ atoms strongly [26], making them ideal components in catalysts for $\mathrm{CO}$ oxidation.

\section{Conclusions}

In this work, we have studied the oxidation of $\mathrm{CO}$ on model and powder catalysts of $\mathrm{Au}-\mathrm{CeO}_{2}$ and $\mathrm{Au}-\mathrm{CeO}_{\mathrm{x}} / \mathrm{TiO}_{2}$. The phenomena observed in $\mathrm{Au}-\mathrm{CeO}_{2}(111)$ and $\mathrm{Au}-$ $\mathrm{CeO}_{2} / \mathrm{TiO}_{2}(110)$ did provide useful concepts for the design and preparation of highly active and stable $\mathrm{Au}-\mathrm{CeO}_{\mathrm{x}} / \mathrm{TiO}_{2}$ powder catalysts for $\mathrm{CO}$ oxidation. Small particles of $\mathrm{Au}$ dispersed on $\mathrm{CeO}_{2}(111)$ displayed high catalytic activity, making the $\mathrm{Au} / \mathrm{CeO}_{2}(111)$ system a better $\mathrm{CO}$ oxidation catalyst than $\mathrm{Au} / \mathrm{TiO}_{2}(110)$ or $\mathrm{Au} / \mathrm{MgO}(100)$. An excellent 
support for gold was found after depositing nanoparticles of ceria on $\mathrm{TiO}_{2}(110)$. The $\mathrm{CeO}_{\mathrm{x}}$ nanoparticles act as nucleation centers for gold, improving the dispersion of the supported metal and helping in the creation of reaction sites which are efficient for the adsorption of $\mathrm{CO}$ and the dissociation of the $\mathrm{O}_{2}$ molecule.

High-surface area catalysts were prepared by depositing gold on ceria nanorods and $\mathrm{CeO}_{\mathrm{x}} / \mathrm{TiO}_{2}$ powders. The samples were tested for the low-temperature $\left(10-70{ }^{\circ} \mathrm{C}\right)$ oxygen-rich $\left(1 \% \mathrm{CO} / 4 \% \mathrm{O}_{2} / \mathrm{He}\right) \mathrm{CO}$ oxidation reaction after pre-oxidation $\left(20 \% \mathrm{O}_{2} / \mathrm{He}\right.$, $\left.300{ }^{\circ} \mathrm{C}\right)$ and pre-reduction $\left(5 \% \mathrm{H}_{2} / \mathrm{He}, 300{ }^{\circ} \mathrm{C}\right)$ treatments aimed at generating different concentrations of ionic $\left(\mathrm{AuO}_{\mathrm{x}}\right)$ and metallic $(\mathrm{Au})$ gold species. The activity tests and the related operando XANES characterizations indicated that both oxidized and reduced gold nanostructures were able to catalyze the oxygen-rich low-temperature $\mathrm{CO}$ oxidation reaction, but the ones in metallic form were more active. Furthermore, even under oxygen-rich conditions, the cationic gold was not stable and a $\mathrm{AuO}_{\mathrm{x}} \mathrm{Au}$ transformation took place. In selecting the proper methods of preparation and pretreatment, the findings of this work rationalize the design of a catalyst with $\sim 1$ at $\mathrm{Au}$ on $\mathrm{CeO}_{\mathrm{x}} / \mathrm{TiO}_{2}$ with hydrogen pre-reduction in order to maximize the concentration of metallic gold active sites.

\section{Acknowledgments}

This research was carried out in part at the National Synchrotron Light Source and the Center for Functional Nanomaterials at Brookhaven National Laboratory, which are

supported by the U. S. Department of Energy, Office of Basic Energy Sciences, under contract DE-AC02-98CH10886. J.E. thanks INTEVEP and IDB for research grants that made possible part of the work done at the Universidad Central de Venezuela. 


\section{References}

[1] M. Haruta, N. Yamada, T. Kobayashi, S. Iijima, J. Catal. 1989, 115, 301.

[2] M. Valden, X. Lai, D. W. Goodman, Science, 1998, 281, 1647.

[3] J.-D. Grunwaldt, A. Baiker, J. Phys. Chem. B, 1999, 103, 1002.

[4] W. Yan, B. Chen, S. M. Mahurin, S. Dai, S. H. Overbury, Chem. Commun., 2004, 1918.

[5] M. Daté, M. Okumura, S. Tsubota, M. Haruta, Angew. Chem. Int. Ed., 2004, 43, 2129.

[6] M. J. Kahlich, H. A. Gasteiger, R. J. Behm, J. Catal., 1999, 182, 430.

[7] W. Deng, C. Carpenter, N. Yi, M. Flytzani-Stephanopoulos, Top. Catal. 2007, 44, 199.

[8] A. A. Herzing, C. J. Kiely, A. F. Carley, P. Landon, G. J. Hutchings, Science, 2008, 321, 1331.

[9] S. D. Gardner, G. B. Hoflund, Langmuir, 1991, 7, 2135.

[10] J.B. Park, J. Graciani, J. Evans, D. Stacchiola, S. Ma, P. Liu, A. Nambu, J.F. Sanz, J. Hrbek, J.A. Rodriguez, Proceedings of the National Academy of Science (PNAS), 2009, 106, 4975 .

[11] J.-L. Lu, H.-J. Gao, S. Shaikhutdinov, H.-J. Freund, Catal. Lett. 2007, 114, 8.

[12] S. Carrettin, P. Concepción, A. Corma, J. M. L. Nieto, V. F. Puntes, Angew. Chem. Int. Ed., 2004, 43, 2538.

[13] A. M. Venezia, G. Pantaleo, A. Longo, G. Di Carlo, M. P. Casaletto, F. L. Liotta, G. Deganello, J. Phys. Chem. B, 2005, 109, 2821.

[14] S. Lai, Y. Qiu and S. Wang, J. Catal., 2006, 237, 303.

[15] U. R. Pillai, S. Deevi, Appl. Catal. A, 2006, 299, 266.

[16] X.-S. Huang, H. Sun, L.-C. Wang, Y.-M. Liu, K.-N. Fan, Y. Cao, Appl. Catal. B, 2009, 90, 224. 
[17] M. Han, X. Wang, Y. Shen, C. Tang, G. Li, R. L. Smith, Jr., J. Phys. Chem. C, 2010, 114, 793.

[18] S. A. C. Carabineiro, S. S. T. Bastos, J. J. M. Órfão, M. F. R. Pereira, J. J. Delgado, J. L. Figueiredo, Appl. Catal. A, 2010, 381, 150.

[19] S. A. C. Carabineiro, A. M. T. Silva, G. Draži , P. B. Tavares, J. L. Figueiredo, Catal. Today, 2010, 154, 21.

[20] J.A. Rodriguez, P. Liu, J. Hrbek, J. Evans, M. Perez, M. Ang. Chem. Int. Ed. 2007, 46, 1329.

[21] Z. Zhou, M. Flytzani-Stephanopoulos, H. Saltsburg, J. Catal., 2011, 280, 255.

[22] H. Zhu, C. Liang, W. Yan, S. H. Overbury, S. Dai, J. Phys. Chem. B, 2006, 110, 10842.

[23] Q. Fu, H. Saltsburg, M. Flytzani-Stephanopoulos, Science, 2003, 301, 935.

[24] W. Deng, J. De Jesus, H. Saltsburg, M. Flytzani-Stephanopoulos, Appl. Catal. A, 2005, 291, 126.

[25] Z.-P. Liu, S. J. Jenkins, D. A. King, Phys. Rev. Lett., 2005, 94, 196102.

[26]. F. Yang, J. Graciani, J. Evans, P. Liu, J. Hrbek, J.F. Sanz, J.A. Rodriguez, J. Am. Chem. Soc. 2011, 133, 3444.

[27] R. Si, J. Tao, J. Evans, J.B. Park, L. Barrio, J.C. Hanson, Y. Zhu, J. Hrbek and J.A. Rodriguez, J. Phys. Chem. C, 2012, 116, 23547.

[28] R. Si, M. Flytzani-Stephanopoulos, Angew. Chem. Int. Ed. 2008, 47, 2884.

[29] N. Yi, R. Si, H. Saltsburg, M. Flytzani-Stephanopoulos, Appl. Catal. B, 2010, 95, 87-92.

[30] Y. Guan, D. A. J. M. Lighthart, Ö. Pirgon-Galin, J. A. Z. Pieterse, R. A. van Santen, E. J. M. Hensen, Top. Catal., 2011, 54, 424.

[31] A. P. Hammersely, S. O. Svensson, A. Thompson, Nucl. Instrum. Methods Phys. Res. 1994, $346,321$. 
[32] A. C. Larson, R. B. von Dreele, GSAS General Structure Analysis System. Report LAUR 86-748, Los Alamos National Laboratory, Los Alamos, NM, 1995. (b) A. M. Rietveld, $J$. Appl. Crystallogr. 1969, 2, 65. (c) B. H. Toby, J. Appl. Crystallogr. 2001, 34, 210.

[33] M. Newville, B. Ravel, D. Haskel, J. J. Rehr, E. A. Stern, Y. Yacoby, Physica B 1995, 208-209, 154.

[34] K. Zhou, X. Wang, X. Sun, Q. Peng, Y. Li, J. Catal., 2005, 229, 206.

[35] H.-X. Mai, L.-D. Sun, Y.-W. Zhang, R. Si, W. Feng, H.-P. Zhang, H.-C. Liu, C.-H. Yan, J. Phys. Chem. B, 2005, 109, 24380.

[36] V. Schwartz, D. R. Mullins, W. Yan, B. Chen, S. Dai, S. H. Overbury, J. Phys. Chem. B, 2004, 108, 15782.

[37] X. Wang, J.A. Rodriguez, J.C. Hanson, M. Perez, J. Evans, J. Chem. Phys. 2005, 123, 221101.

[38] D. Tibiletti, A. Amiero-Fonseca, R. Burch, Y. Chen, J.M. Fisher, A. Goguet, C. Hardacre, P. Hu and D. Thompsett, J. Phys. Chem. B, 2005, 109, 22553.

[39] A. I. Frenkel, Q. Wang, N. Marinkovic, J. G. Chen, L. Barrio, R. Si, A. López Cámara, A. M. Estrella, J. A. Rodriguez, J. C. Hanson, J. Phys. Chem. C, 2011, 115, 17884.

[40] A.C. Johnston-Peck, S.D. Senanayake, J.J. Plata, S. Kundu, W. Xu, L. Barrio, J. Graciani, J.F. Sanz, R.M. Navarro, J.L.G. Fierro, E.A. Stach, J.A. Rodriguez, J. Phys. Chem. C, 2013, $117,14463$.

[41] S. Kundu, J. Ciston, S. Senanayake, D.A. Arena, E. Fujita, D. Stacchiola, L. Barrio, R. Navarro, J.L.G. Fierro, J.A. Rodriguez, J. Phys. Chem. C 2012, 116, 14062. 


\section{Figure Captions:}

Figure 1. $\mathrm{CO}$ oxidation activity of $\mathrm{Au} / \mathrm{CeO}_{2}(111)$ and $\mathrm{Au} / \mathrm{CeO}_{\mathrm{x}} / \mathrm{TiO}_{2}(110)$ as a function of $\mathrm{Au}$ coverage. The area covered by ceria on the titania substrate was measured by ion-scattering spectroscopy [10], before depositing gold, and was found to be $\sim 8$ and $27 \%$ of the clean titania. The reported values for the production of $\mathrm{CO}_{2}$ were obtained after exposing the catalysts to 4 Torr of $\mathrm{CO}$ and 2 Torr of $\mathrm{O}_{2}$ at $27^{\circ} \mathrm{C}$ for $5 \mathrm{~min}$.

Figure 2. Maximum production of $\mathrm{CO}_{2}$ during the oxidation of $\mathrm{CO}$ on $\mathrm{Au} / \mathrm{MgO}(100)$, $\mathrm{Au} / \mathrm{TiO}_{2}(110)[10]$ and $\mathrm{Au} / \mathrm{CeO}_{2}(111)$. The amount of gold deposited on the oxide supports was 0.3-0.4 ML. The reported values for the production of $\mathrm{CO}_{2}$ were obtained after exposing the catalysts to 4 Torr of $\mathrm{CO}$ and 2 Torr of $\mathrm{O}_{2}$ at $27^{\circ} \mathrm{C}$ for $5 \mathrm{~min}$.

Figure 3. TEM (a, c) and HRTEM (b, d) images of 1 at.\%Au-CeO ${ }_{2}$ samples: (a) Fresh; (b) Preoxidized with $\mathrm{O}_{2}$ and used in $\mathrm{CO}$ oxidation; (c, d) Pre-reduced with $\mathrm{H}_{2}$ and used in $\mathrm{CO}$ oxidation.

Figure 4. $\mathrm{CO}$ conversion as a function of temperature for pre-reduced $\mathrm{Au}-\mathrm{CeO}_{2}$ nanorod and $\mathrm{Au}$ $\mathrm{CeO}_{\mathrm{x}} / \mathrm{TiO}_{2}$ catalysts (Pre-reduction conditions: $5 \% \mathrm{H}_{2} / \mathrm{He}, 200{ }^{\circ} \mathrm{C}, 1 \mathrm{~h}$. Testing conditions: $1 \%$ $\mathrm{CO} / 4 \% \mathrm{O}_{2} / 95 \% \mathrm{He}, 20 \mathrm{~mL} / \mathrm{min}, 25 \mathrm{mg}$ catalyst).

Figure 5. Operando XRD $(\lambda=0.3196 \AA)$ patterns of a pre-reduced $\mathrm{Au}-\mathrm{CeO}_{2}$ nanorod catalyst collected a different temperatures (Temperature range $=10-70{ }^{\circ} \mathrm{C}$. Testing conditions: $1 \% \mathrm{CO} / 4 \% \mathrm{O}_{2} / \mathrm{He}, 20 \mathrm{~mL} / \mathrm{min}, 25 \mathrm{mg}$ catalyst)

Figure 6. Operando XANES (Au L-III edge) spectra for the $\mathrm{Au}-\mathrm{CeO}_{2}$ nanorod catalysts. (Testing conditions: $1 \% \mathrm{CO} / 4 \% \mathrm{O}_{2} / \mathrm{He}, 20 \mathrm{~mL} / \mathrm{min}, 25 \mathrm{mg}$ catalyst, $25^{\circ} \mathrm{C}$.)

Figure 7. Linear combination results for the oxidation states of gold species as a function of reaction time when performing the low-temperature oxidation of $\mathrm{CO}$ on pre-oxidized and prereduced $\mathrm{Au}-\mathrm{CeO}_{2}$ nanorod catalysts (Testing conditions: $1 \% \mathrm{CO} / 4 \% \mathrm{O}_{2} / \mathrm{He}, 20 \mathrm{~mL} / \mathrm{min}, 25 \mathrm{mg}$ catalyst, $25^{\circ} \mathrm{C}$ ). "OX" denotes a fully oxidized sample, and "RE" a fully reduced one. 
Figure 8. Possible routes for the activation of $\mathrm{Au}-\mathrm{CeO}_{2}$ nanorod catalysts under different reaction conditions.

Figure 9. TEM (A) and HRTEM (B) images for a pre-reduced $\mathrm{Au}-\mathrm{CeO}_{\mathrm{x}} / \mathrm{TiO}_{2}$ catalyst.

Figure 10. $\mathrm{CO}$ conversion as a function of time for a pre-reduced $\mathrm{Au}-\mathrm{CeO}_{\mathrm{x}} / \mathrm{TiO}_{2}$ catalyst (Testing conditions: $1 \% \mathrm{CO} / 4 \% \mathrm{O}_{2} / 95 \% \mathrm{He}, 20 \mathrm{~mL} / \mathrm{min}, 25 \mathrm{mg}$ catalyst). 
Figure 1

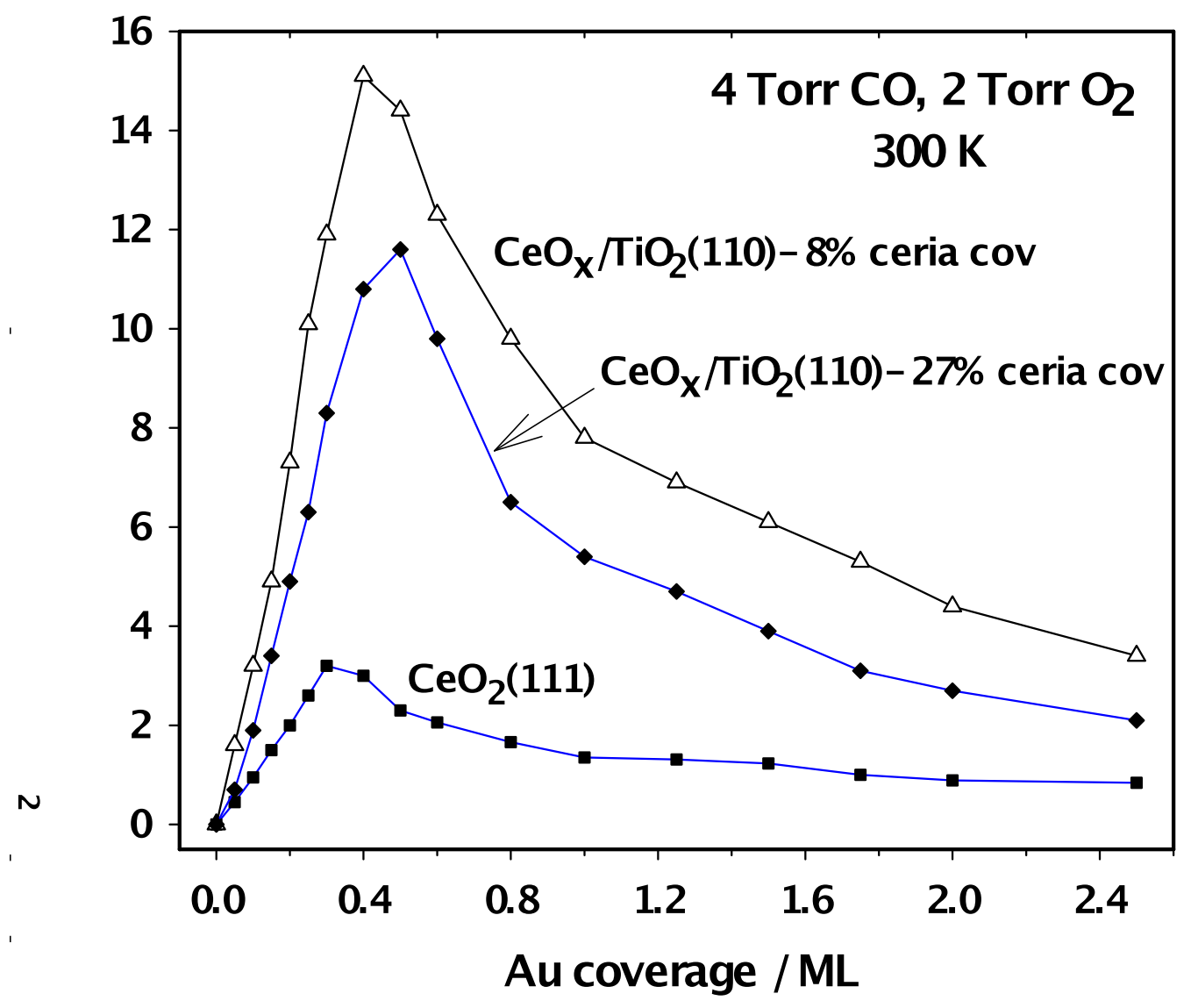


Figure 2

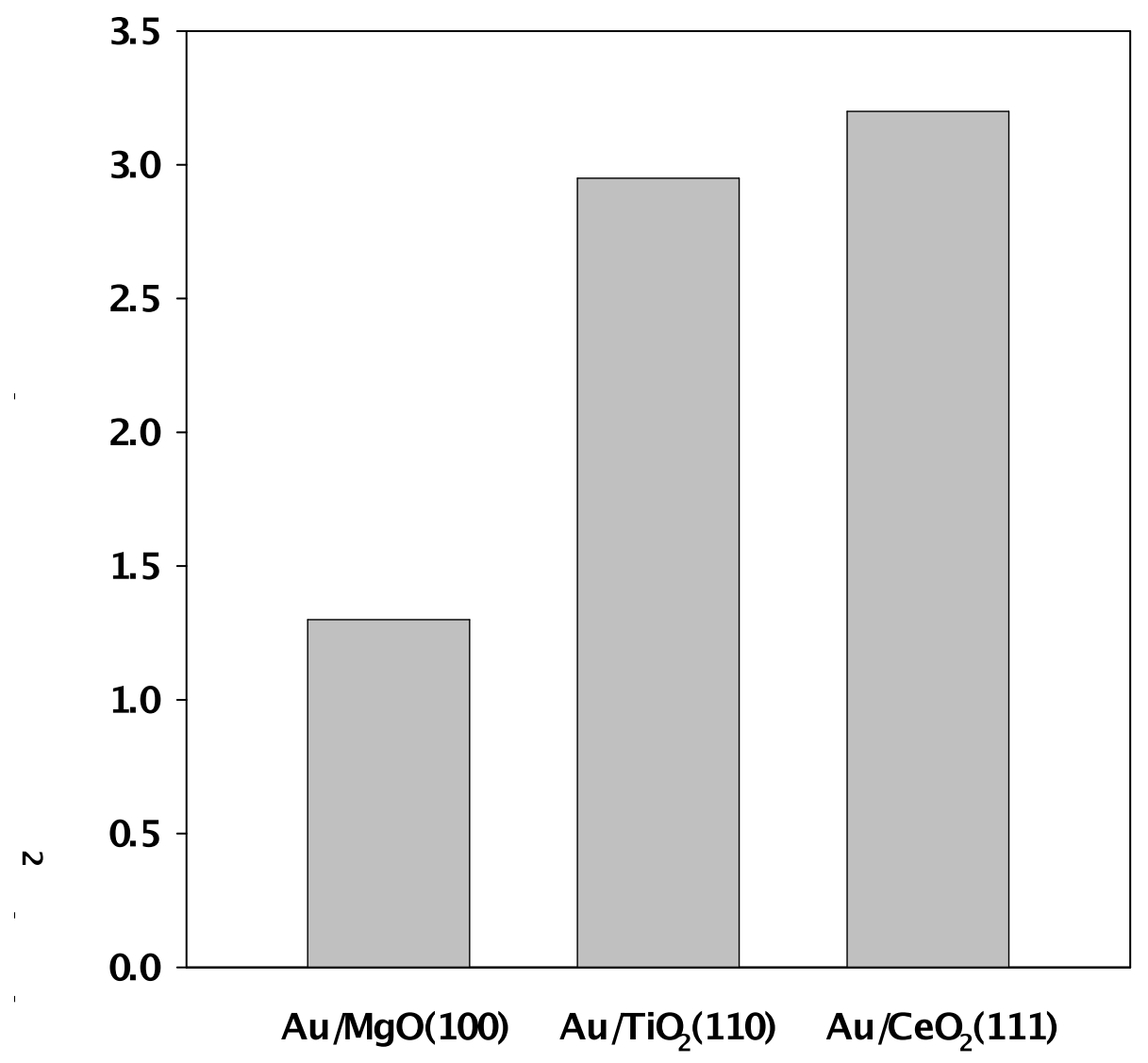


Figure 3

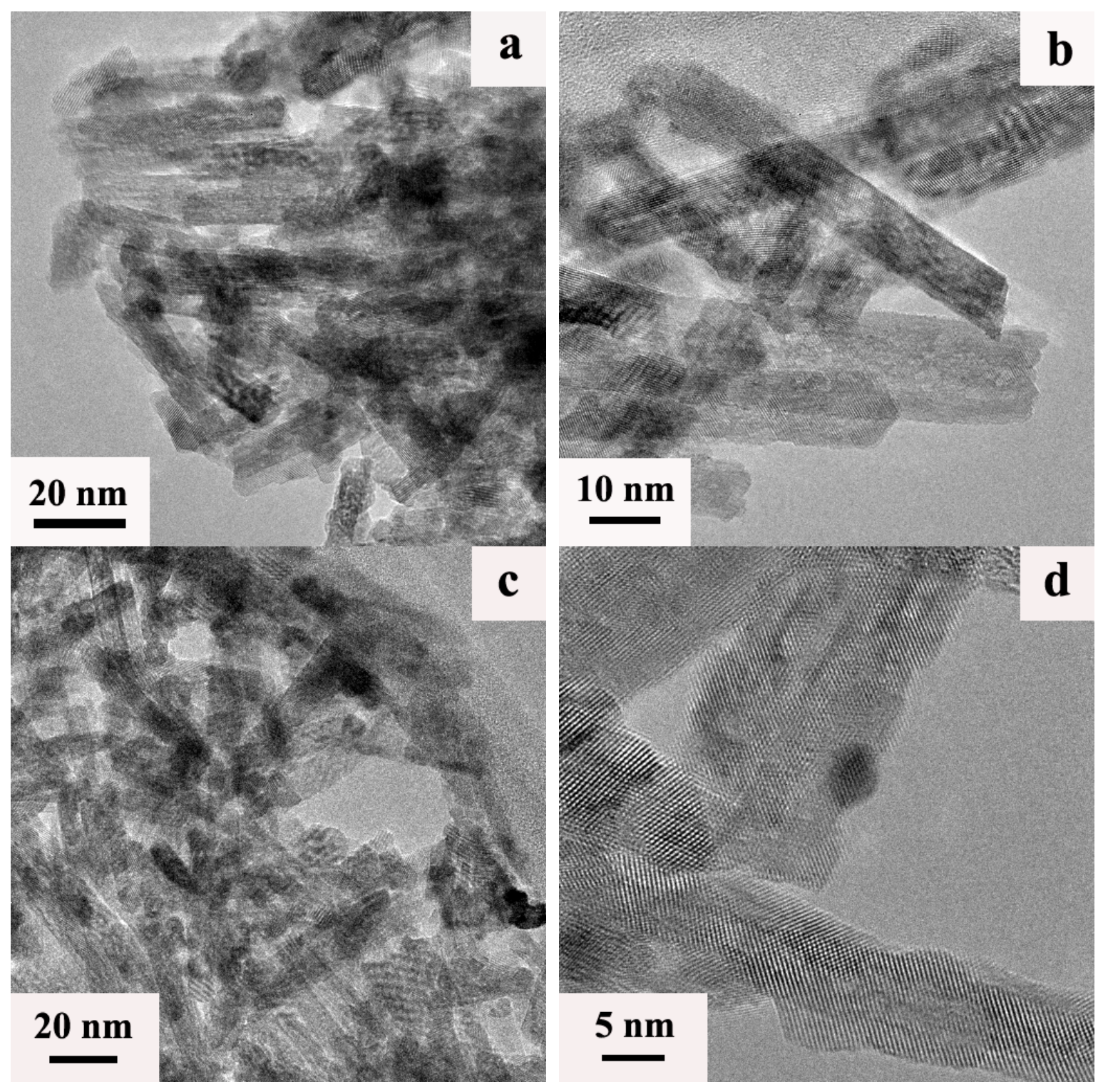


Figure 4

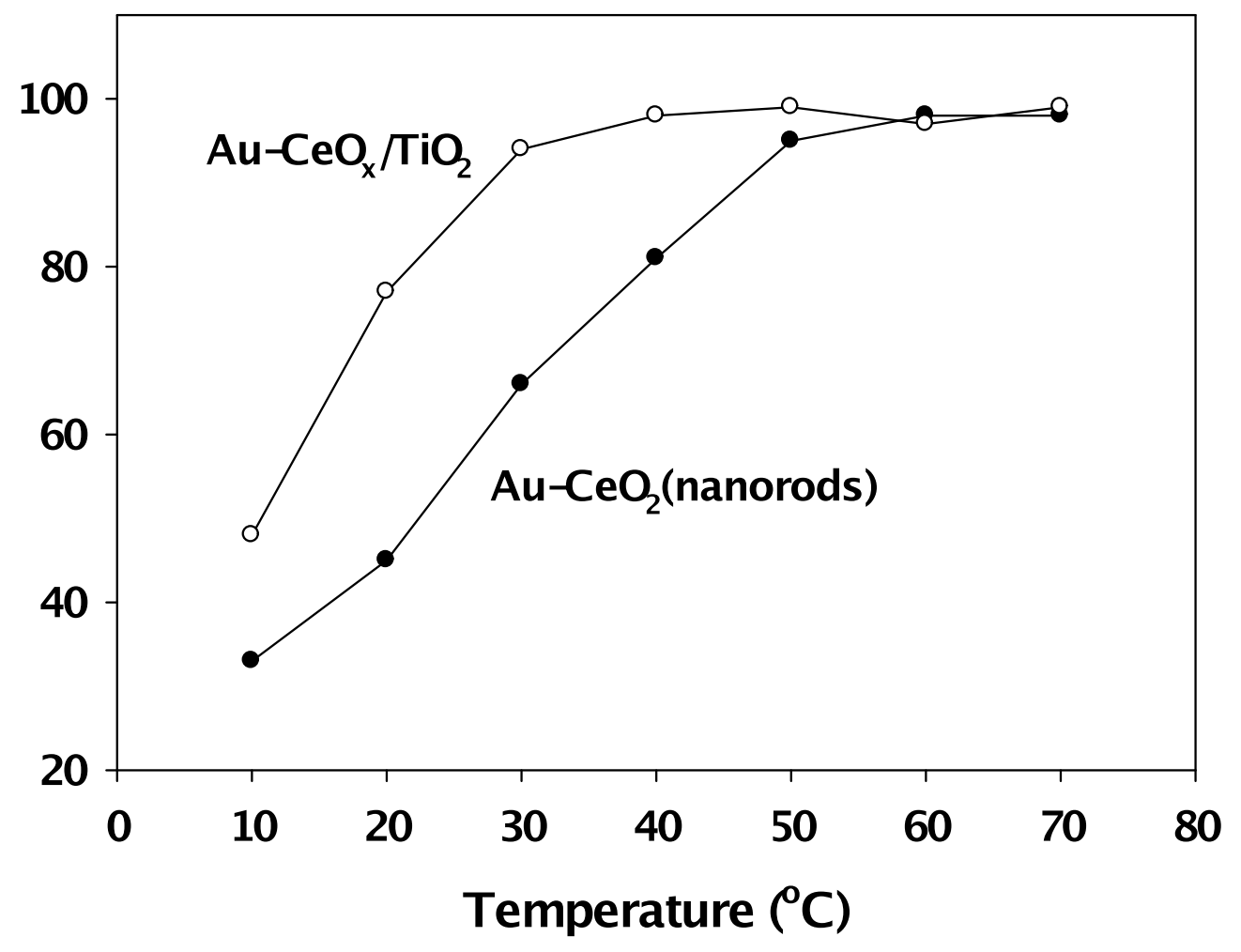


Figure 5

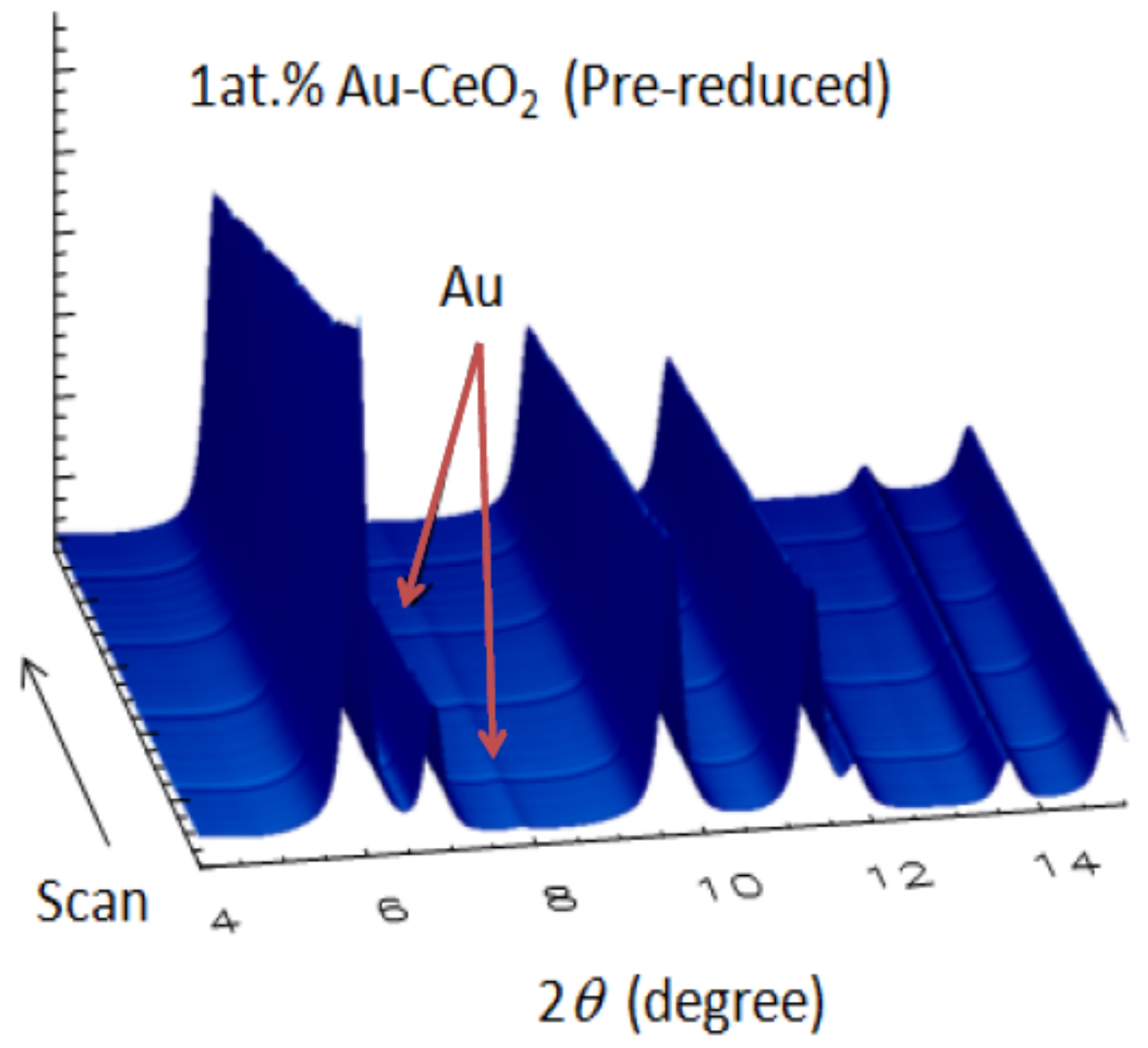


Figure 6

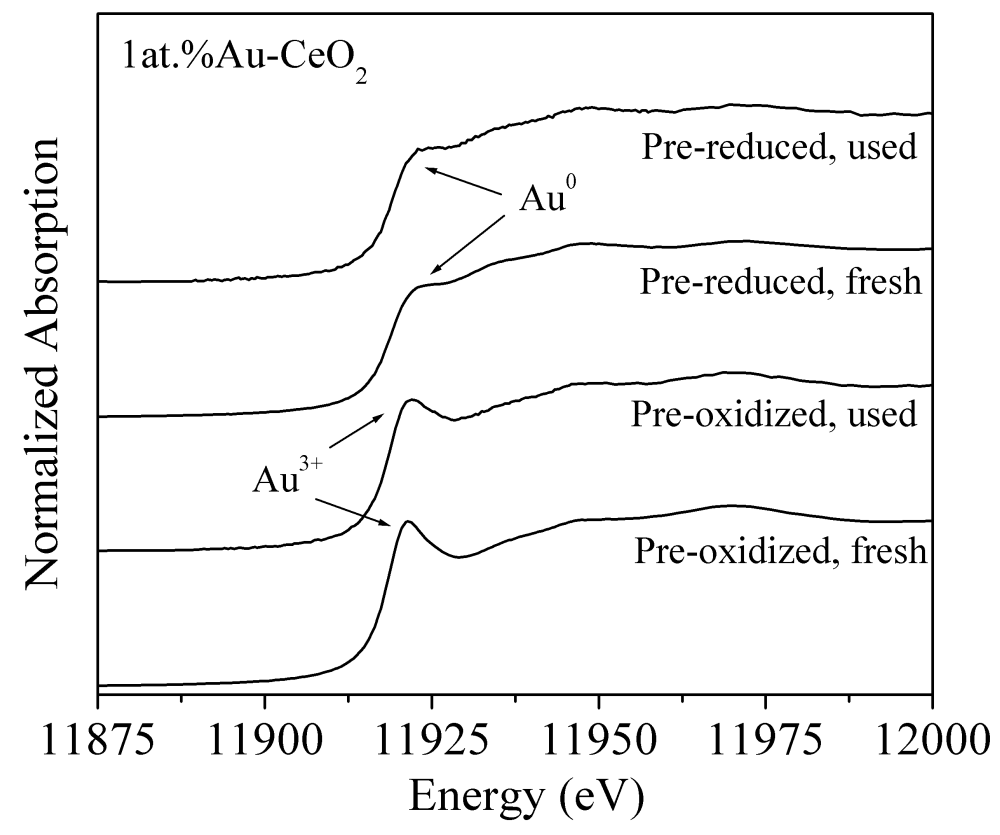


Figure 7

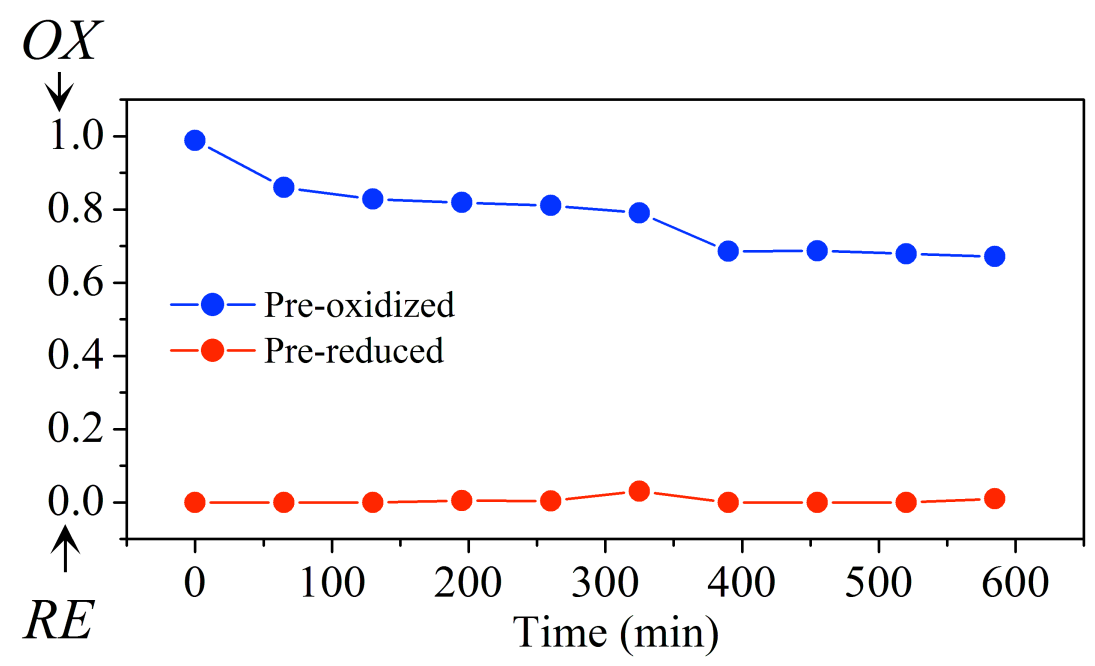


Figure 8

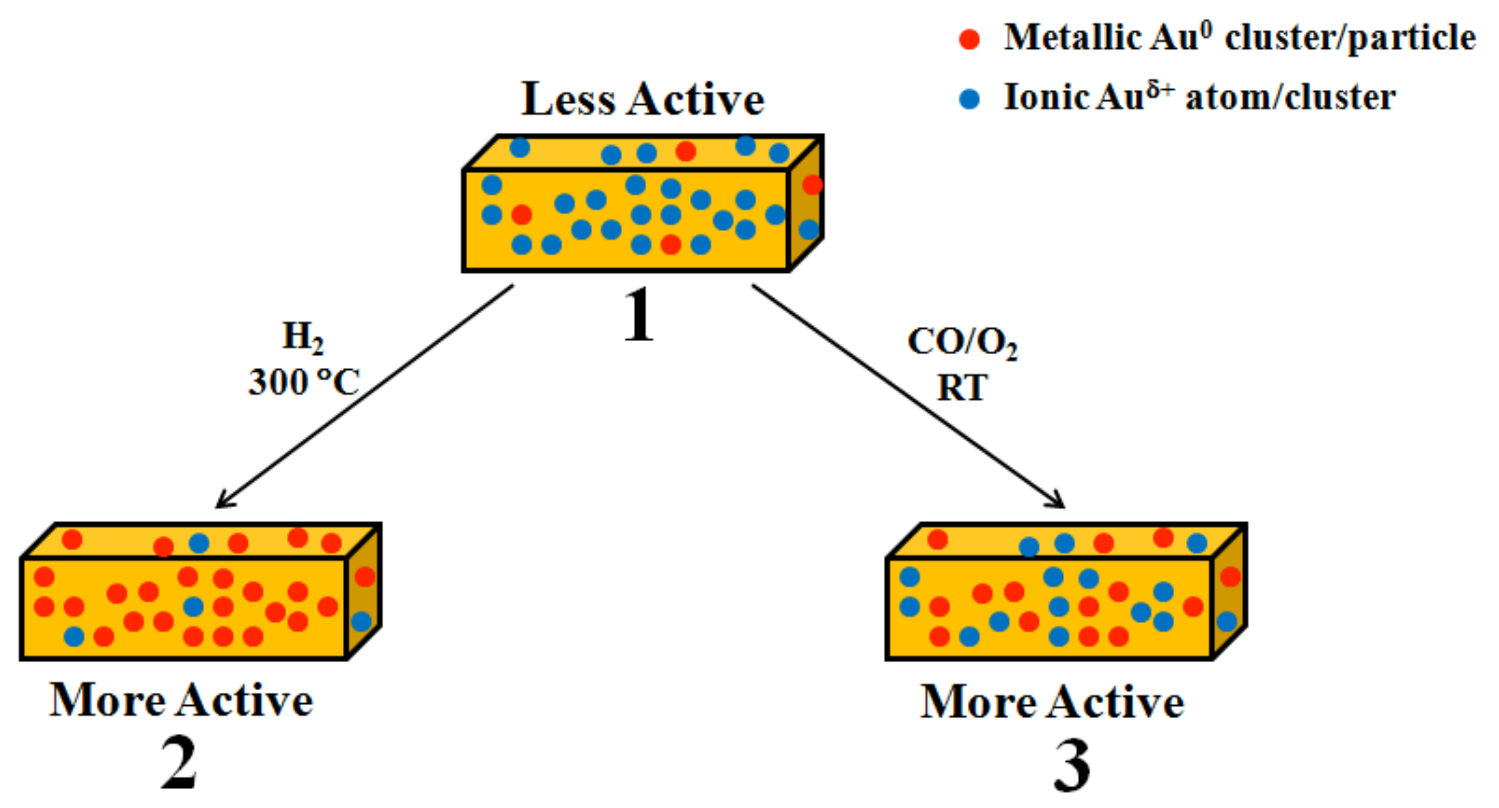


Figure 9
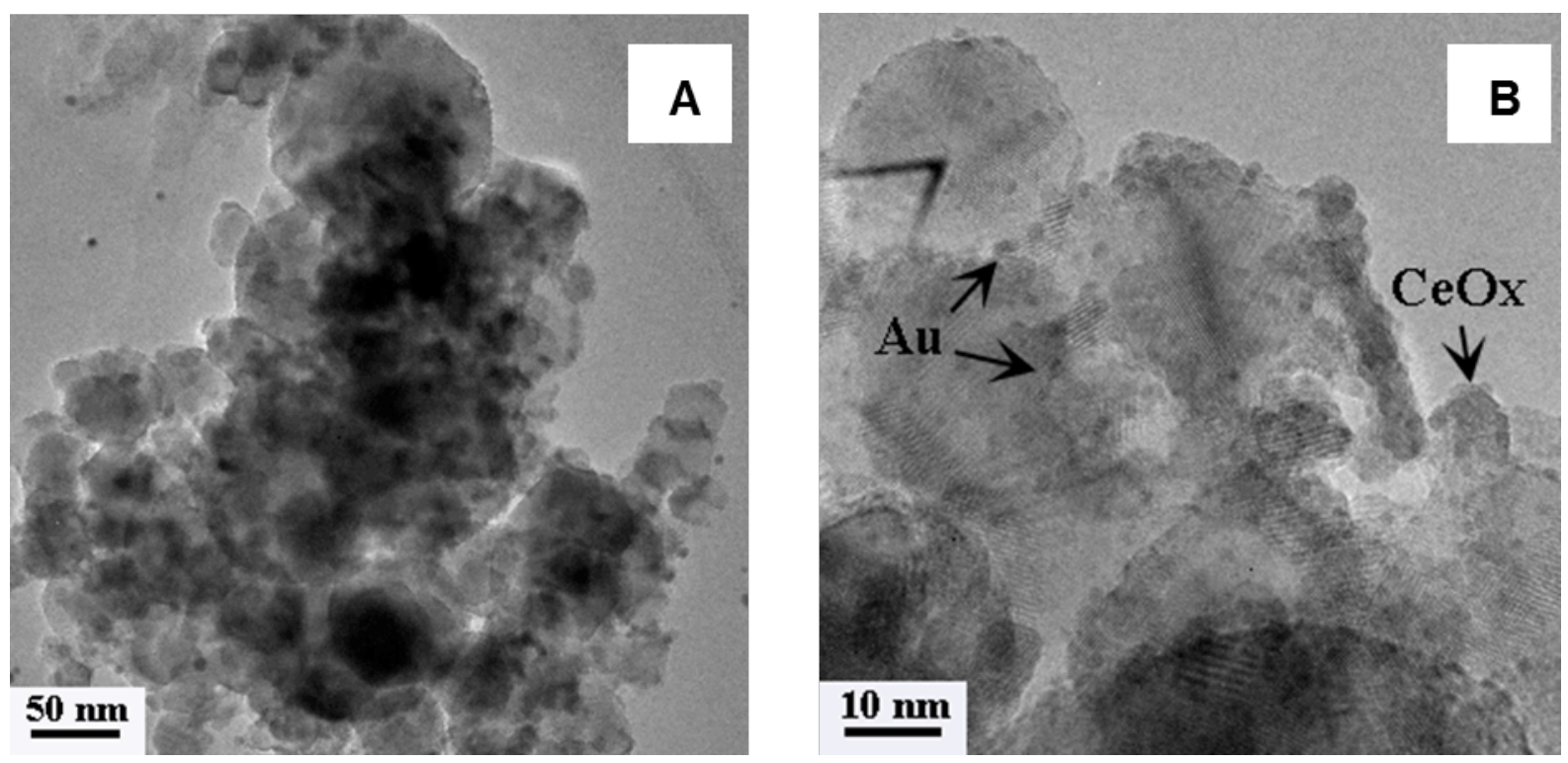
Figure 10

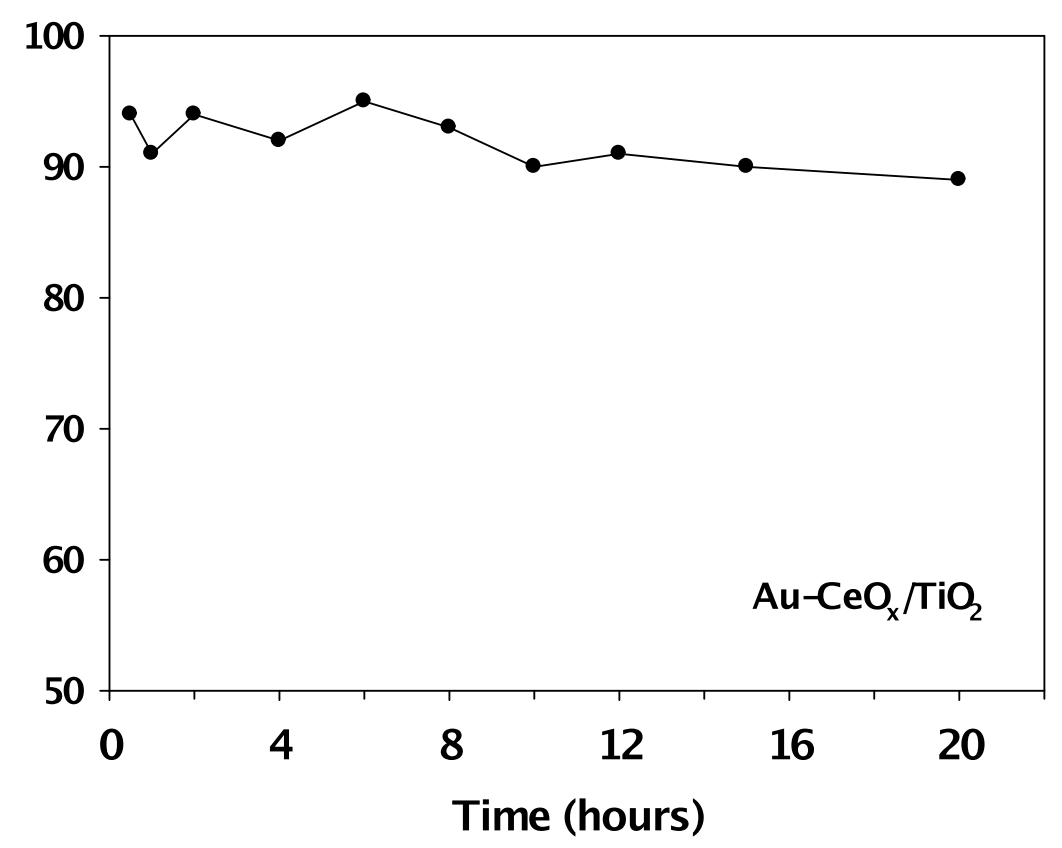




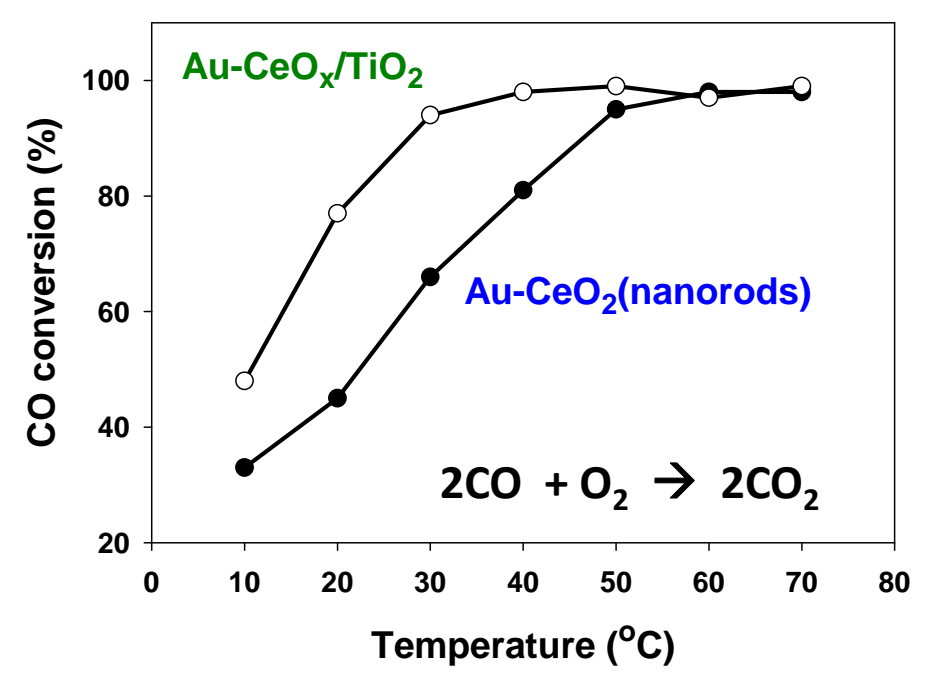

Graphical abstract 